\title{
The Way That Lives in the Heart
}

Chinese Popular Religion and

Spirit Mediums in Penang, Malaysia 

JEAN DEBERNARDI

\section{The Way That Lives in the Heart}

Chinese Popular Religion and

Spirit Mediums in Penang, Malaysia

S T A N F OR D U N IVERS I T Y PRES S

Stanford, California 2006 
Stanford University Press

Stanford, California

(C) 2006 by the Board of Trustees of the

Leland Stanford Junior University

Library of Congress Cataloging-in-Publication Data

DeBernardi, Jean Elizabeth.

The way that lives in the heart : Chinese popular religion and spirit mediums in Penang, Malaysia / [Jean DeBernardi].

$$
\text { p. } \mathrm{cm} \text {. }
$$

Includes bibliographical references and index.

ISBN 0-8047-5292-3 (alk. paper)

1. Pinang-Religious life and customs. 2. Chinese-PinangRites and ceremonies. 3. Chinese-Malaysia-Rites and ceremonies. I. Title.

BL2080.D43 2006

$299.5^{\prime} 1095951-\mathrm{dc} 22$

2005031346

Printed in the United States of America

Original Printing 2006

Last figure below indicates year of this printing:

$\begin{array}{llllllllll}15 & 14 & 13 & 12 & 11 & 10 & 09 & 08 & 07 & 06\end{array}$

Typeset at TechBooks, New Delhi, in 10/12.5 Minion 